\title{
Case Study: A Sample of Slip Painted Buff Ware to Treasury of Tehran BONYAD Museum
}

\author{
Najmeh Nouri \\ Faculty of Preservation and Restoration, Department of Archaeology, Isfahan University of Art, Isfahan, Iran
}

\section{Email address:}

noori_najmeh@yahoo.com

\section{To cite this article:}

Najmeh Nouri. Case Study: A Sample of Slip Painted Buff Ware to Treasury of Tehran BONYAD Museum. International Journal of Archaeology. Vol. 4, No. 4, 2016, pp. 36-43. doi: 10.11648/j.ija.20160404.11

Received: April 29, 2016; Accepted: June 8, 2016; Published: June 23, 2016

\begin{abstract}
Pottery production within Islamic lands including Iran in Samanid era went through profound changes. At this time, slip painted pottery is among the most beautiful and, at the same time, mysterious pottery in Islamic eras having various ornamental patterns. At museums and diverse collections of the world, there exist so many samples of this pottery kind, some of them having certificate and some have not been studied yet. At Treasury of Tehrn's Bonyad Museum, a sample of slip painted Buff ware by a motif in the form of a man holding a cup is preserved that to date no information around it has been published. In this study, this object will be introduced. The study was conducted through a corresponding - descriptive method and its date collection was done by field and attributive method within which corresponding the object under study with certificated samples in other collections was done with the aim of introducing and answering to these two questions where and when the probable construction site and date of this pottery is. Finally, this result was achieved that this sample is among Nishapur's productions and relating to the third and fourth centuries (LY).
\end{abstract}

Keywords: Slip Painted Buff Ware, Bonyad Museum, Nishapur, $3^{\text {rd }}$ and $4^{\text {th }}$ centuries (LY)

\section{Introduction}

By Islam appearance in the first half of seven century AC, pottery production all-around of Islamic lands gradually underwent salient changes. At the beginning, potters followed preceding methods and traditions. This occurrence, however, did not last more than over two centuries. Commercial communications with Far East, especially China, and flow of Chinese goods and pottery to Islamic lands, on the one hand, and restriction of Islamic laws about using gold and silver pots Caused Developments in pottery production and followed by appearance of novel and various types. Islamic potters applied numerous experiences and experiments and through modeling some Chinese cases and free of mere imitation of used novel techniques in pottery production. Abundance of the cases attributed to eastern Islam world is indicative of this thing that slippery painting has been the most general pottery ornament in Iran' s eastern lands in the early Islamic centuries. This Pottery Kind was Known as Samanid pottery, in that, it was made more in Samanid Era (359 - $204 \mathrm{LY} / 819$ - 1005 AC) and around this
Government' s borders including Khorasan, Mavra - ol Nahr and Kirman. These productions manifest a totally different esthetics from other pottery being simultaneously made in Iran and Iraq. The ornamentation method of such productions and also application of wide range of colors have made this pottery kind as one of the most attractive and, at the same time, mysterious pottery of Islamic eras. The decorating quality of these potteries is to such an extent that many researchers consider their beauty beyond Gold imported potterie, then from Iraq. In this article, a sample of slip painted pottery with a motif of a man holding cup location in Tehran Bonyad museum will be introduced. Therefore, it seems necessary to answer these questions: 1. what date is the slip pottery Buff ware motif of a man holding cup in treasury of Tehran's Bonyad Museum related? 2. What region does this object belong to? Identification of built method (technology) and damage kind (pathology) causes to recognize and choose the appropriate method of object article. Therefore, the object was first studied and noticeable points were and noted. then color imaging was done from different angles. Then digital lope was applied in order to further study superficial damages. After that 
documentation, drawing and measurement were conducted for technically drawing the object. Also, to respond the questions, researches and main study resources of this pottery kind, report of related archeological excavations and examinations were precisely studied. Then built center and relative dating were specified. The first survey and comprehensive introduction of Slip pots was done by Wilkinson in the form of study and publication of abundant pots resultant from Metropolitan museum excavations of Nishapur. He, in addition to studying and publishing the discovered material, offered the first specific classification for this kind of pots having been done more by considering ornament Technique, motifs color and work bed and caused creation of a pattern having been accepted by many scholars [27]. Other researchers also, by following Wilkinson's classification or offering a new one, devoted Islamic pottery publication to study and analysis of this pots' type [12], [5], [8], [6], [26], [9], [18]. Also studied about koufi inscription of this kind of pots. Some types of slip painted pots have also been introduced and examined in theses [3] and the articles resultant from archaeological excavation and examinations in different regions [16], [14], [15], [16]. The various motifs of these pots have been examined by several researchers such as Fitzherbert study [7]. Bullit also with a different approach has embarked on studying pottery's diverse styles and their relationship with various social positions [2]. Some scholars including shobeirie Douzini belive that in Nishapur's samani pots, besides samanid art, the effects of Manavi, Byzantine, and saqdi art, etc are also identifiable in these Pictures [21] and some such as Hosseini Yazdi Consider Nishapur's pots as the first visual works of early Islamic era. Hosseini Yazdi, [10] and Ataei [16] also by referring to archeological evidence, in addition to Nishapur, Afrasiab (Old Samarqand), show wide regions including central Asia, great korasan, Sistan, a part of Southern seashores of Caspian Sea and Kirman as the spread limit of slip painted pottery. Moreover, Tamaddon Yazdian, begins to study about slip, or muddy coverage, application in Iran's pottery history from Neolithic era to Ilkhanid era [23]. Some researchers have also put construction and ornament techniques and execution method of slip pottery under consideration and study [11] However, to date no study has been done on slip painted buff wares, located in Tehran's Bonyad museum. At Treasury of Tehran' s Bonyad Museum, a sample of slip painted Buff ware by a motif in the form of a man holding a cup is preserved that to date no information around it has been published. In this study, this object will be introduced.

\subsection{Pottery in Samanid Era}

The most complete samples of Samanid art could be observed in its pottery. In Samani era, for the pots produced under the influence of pots belonging to China's Tang dynasty, there exist pots achieving high extent of elegance. The applied technique in these pottery, Being Peculiar to Mavra - ol - Nahr, resultant from mixing metal oxid for coloring with m muddy glaze coating. These pots rooting in Mavra - ol - Nahr the Third - Century (LY) / Ninth Century
(AC), enjoyed widespread popularity in all around of Iran's eastern states. These pots were being exported to eastern Sind (Brahman Abad and Bam pour) and Sawed and to Western Susa (Shratu, 1997, 64 - 65). In fact, Iran's geographical position as the central point in east and west route caused Iran's communication with diverse cultures and civilizations and Iranian potters in efforts to achieve Chinese white pots discovered a novel method named slip painted [25], And it is considered as a paramount method for coating clay products. One of the features relating to Samani era's pottery is to be impressed and artist's return to last artistic traditions regarding governing thought flow and so many inspirations getting from Sasani era.

This era's potters as tried in making potters and using them instead -of metal pots of Sasanid era's, also enjoyed the motifs of silver and gold pots in pottery [29]. This Way they have inherited the congruence concept and motif genuineness from Sasani's art. Sasani's pottery art has always been of a special artistic tradition having not diverted from its course and Iranian artists have coordinated the adopted motifs and patterns with Iranian taste in maximum tact and skill and despite adoptions from other civilizations in its own turn, we could point to Majolica, Delft, Lambet, and Norse pottery, to name a few (Alan, 2004: 7).

Among other features of Samani's is that While Being helpful, it was also considered as an ornamental work. The ornament artist has depicted their imaginations and mental conceptions from nature and abstained mere imitation probably considered as most great artists' ideal (Vaye, 1984: 68).

These pots 'motifs having high quality follow special rules and their drawing is not chance. The artist creates a regular undulation through combining leaves in circle shape with snail forms and makes an orchestra (Ibid: 71 -72). The Potter has enjoyed such different methods as symmetry - making, going through detail, and executing overwrought motifs to create harmony and homogeneity in the work and ignored natural effects like perspective and penumbra.

\subsection{Slip Painted Pottery in Third and Fourth Centuries (LY)}

Use of slip as muddy coverage to cover and smooth rough surface has been common long time ago (at pre - history) in pottery industry. Slip's based on potter's tastes were sometimes being chosen as the same material and color as the clay pot and sometimes based on their idea being used with a color different from the pot's paste color. They were being used not only with applying muddy coverage, but like an appropriate bed for lots of ornamentation such as painting and / or engraved motif (Shateri, 2009: 139). In the 3rd and 4th centuries (LY), Iranian potter's imitation from Chinese pottery let them achieve slippery pottery. They, on the way to achieve white pottery, decided to attain this through covering colored bodies by white material. the white material could be white wash and / or white opaque glaze. This glaze producing a completely white surface rapidly spread from Iran to all Islamic countries and to Spain and there became known as 
Majolica pottery (Wolf, 1994: 130).

In slip painted pottery, ornamentation was created on them through painting and color materials are slip - added, i.e., at first clay body of pot being made from cream or red paste (mud)was being covered with a slip layer and then motifs were being created on the coverage through color materials mixed with a kind of muddy mediator. At the end, pot surface was being covered with leaden glaze (Fehervari, 2000: 50).

Iranian pottery in Samanid era is distinct among the rest of clay pots in Islamic era with respect to build method and variety in quality and execution (Grube, 2005: 45). The first distinct classification for this kind of pottery was offered by Wilkinson (1973). His classification was more done based on ornament technique and color of motifs and work bed that lots of researchers agree with it and apply it with brief changes, Sometimes (Fehrevari, 2000: 50).

Nonetheless, some classifications have been also done based on motifs type (inscriptional, geometric, plant, human, etc.) (Watson, 2004: 205 - 251).

The most common classification for this kind of pottery being offered by Wilkinson and based on ornamentation technique and motifs and bed color is as follows: 1. Black on White ware, 2. Slip-painted Ware with Colored Engobe, 3. Ware with Yellow-staining Black, 4. Opaque White Ware and Its Imitations. 5. Buff Ware 6. Polychrome on White Ware.

In continue, we will consider slip painted Buff ware being the clay case under study in this research and then introduce a sample of slip painted Buff ware located in Tehran Bonyad Museum.

\subsection{Slip Painted Buff Ware}

Wilkinson (1973) has called this group as "Buff ware "because of their "cream pots ". But according to the fact that lots of slip painted pots contain cream Buff, this term does not become peculiar to this group. Thus, some researchers as Fehervari name this category of potteries as Nishapur pottery. (Fehervari, 2005, 50)

All around the pottery has been covered with rich various ornamentation such as birds, animals, human statues, the palm leaves, leafy ivies and inscription (Whitehouse, 1992: 310). Although in this kind of pottery human statues hold a notable statues in ornamenting pots, animal motifs are more repeated. Some of these motifs manifest revival and survival of Sassanid traditions (Fehrevari, 2000: 51). Hence, increase in producing cream pottery with pictures again vivifying preIslamic contents and Sasani era in the fourth century (LY) could be interpreted as in union with development of ancient Iran's artistic and cultural revitalization trend in these eras this trend clearly manifests itself in such arts as metalwork, architecture and also literature.

Buff wares achieved in excavations of the 1930s and 1940 s are among the greatest pottery secrets of Iran in Islamic era (Grube, 2005: 45). these being also famous as colorful crocks were acquired from the most fathomless well stories and basements of Nishapur and their built date back to the early third century (LY) (Dimmond, 1957: 162) The term "buff ware", not only relates to ornamentation but also to the main color of pottery being only observable on the container base (pancaroghlu, 2007: 81). Slip painted buff ware of Nishapur have not been produced before the third (LY) and ninth century (AC) and were being built during the two centuries of the third and Forth (LY) ninth and tenth (Ac) and in early fifths century (LY) early eleventh century (AC) their built was abolished (Wilkinson, 1973: 3)

These clay pots were also known as peasant ware and folk ware (Watson, 2004: 247).

In slip painted Buff ware, human statues and simple animals have been designed (Fehervari, 2000: 50) and this feature caused that they usually became known as peasant or folk ware (Watson, 2007: 25; Lane, 1974: 274). Use of human and animal motifs in cream pottery was not unique and acquired some effects from gold pottery made of Iraq and Iran at that time (Fehervari, 2000: 50, Wilkinson, 1973: 3) According to Shratu, difference between animal kinds and not observing scale in animals size (predators were exorbitantly smaller than hunt) create a diverse scene (Shratu, 1997: 66).

Aesthetics study and stratigraphy lead to comparison between these motifs and painting traditions of Sasani, Abbasi, central Asia and Manavi thoughts, Nastouri and other groups (Watson, 2004: 247). Despite this theory, it seems that these pots probably depict members of ruling party were being made for them (Morgan, 1994: 58).

Slip painted Buff wares, in view of number, are among one of the greatest discovered groups in Nishapur. Some scholars consider these crocks as the ones with everyday use. The feature of these ones is to make images with marginal lines in black color of manganes (Wilkinson, 1973: 3, Rogers, 1995: 260)

This group of crocks is Characterized with a yellowish and rarely mustard background that multi-color compact ornamentation with green, manganese purple, tomato red, yellow, mustered, and white colors have been painted on it and covered with colorless leaden glaze. In this kind, colors are more transparent than other slip painted pottery.

Mud color and slip of background for this kind of buff wares is dominantly buff, but in some case this slip color is clear that it can be called as ivory-colored (Wilkinson, 1973, 4: Fehrevari, 2000, 50: Morgan, 2005: 53)

Wilkinson believes that fine samples of these works are of ivory background. In some types, an opaque yellow has covered all around the background (Wilkison, 1973: 6). It's said, however, that cream pottery were peculiar to Nishapur and were not produced elsewhere (Fehervari, 200: 50). Several pieces were acquired with simple ornamentation in Marv and Afrasyab (Wilkinson, 1973: 3, Watson, 2004: 248). Some samples were also found in Gorgan and Qomes (between Simnan and Shahroud) (Wilkinson, 1973: 3)

\section{Introducing the Case Under Study}

At No.1 pottery treasury of Tehran Bonyad museum, there exists a sample of slip painted pottery Buff ware a motif of a man holding a cup in his hand. This clay pot was registered with $23 \mathrm{~cm}$ in mouth diameter $9 / 6 \mathrm{~cm}$ in base diameter, $9 / 5$ 
$\mathrm{cm}$ in height with number 42380 .

\subsection{Technology (Main Structure of Object Body)}

The body is made of clay and cream in color that in some parts becomes a bit reddish. It is necessary to note that the body, besides clay as the main material, contains sand granules being observable in from of black, red and gray tiny grains. The bell sound hearted by tapping the object indicates that pot has been cooked well. All around the pot has been covered by light slip and then motif has been executed on it. The pot inside is of motif and color and to color the object the red, green, black, and yellow colors were used. On pot's bottom a motif of a standing man with birds surrounding has been drawn having been confined by two circles. the pot's inside walls have been ornamented with a motif like heart in black color having a frequent from and painted with definite distances. To color the main motif being at the pot center (human statue), the red color was used and green color is also observable in the form of blotches sprayed on the statue's body and clothes. In order to color the bird motif also the black color was only used. Finally, the whole pot has been covered with a transparent and colorless glaze having little diameter. The body texture is semi - compact and for preparing pot's paste (mud) a kind of fillers like sand has been used. With respect to color dispersion and the transparent and colorless glaze being cut off in some parts, the pot's construction technique is probably glaze - beneath (painting under glaze) (Fig. 1).

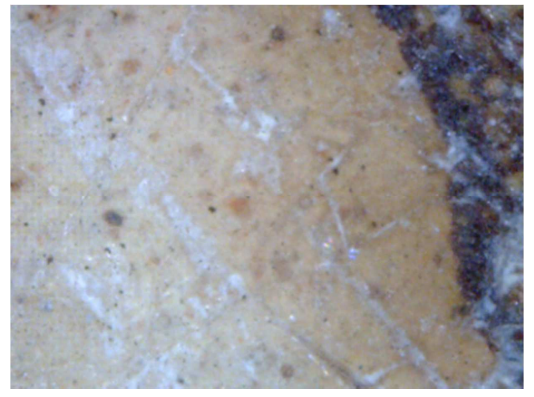

Fig. 1. Color dispersion beneath colorless glaze.

This pot has been made using potter's wheel. The evidence for that is the existence of parallel corrugations being the contact place of hand on mud and is are observable on exterior surface and pot bottom. Also, the whole form is symmetrical (Fig. 2).

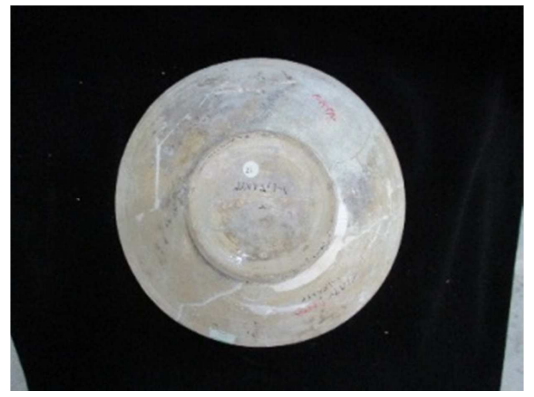

Fig. 2. Existence of parallel corrugations on object's bottom.

\subsection{Microscopic Analyze}

Colors: as mentioned before, to ornament pot the yellow, black, and red colors have been used (Fig. 3). The interesting point is lack of color bedding before ornamenting the clay pot and interior and exterior background color of the pot is fairly the same. Use of colors is of particular order. It is probable, however, that the first color used was black to execute and round motifs. In continue, an image of available colors in ornamenting object is presented having been photographed by lope.

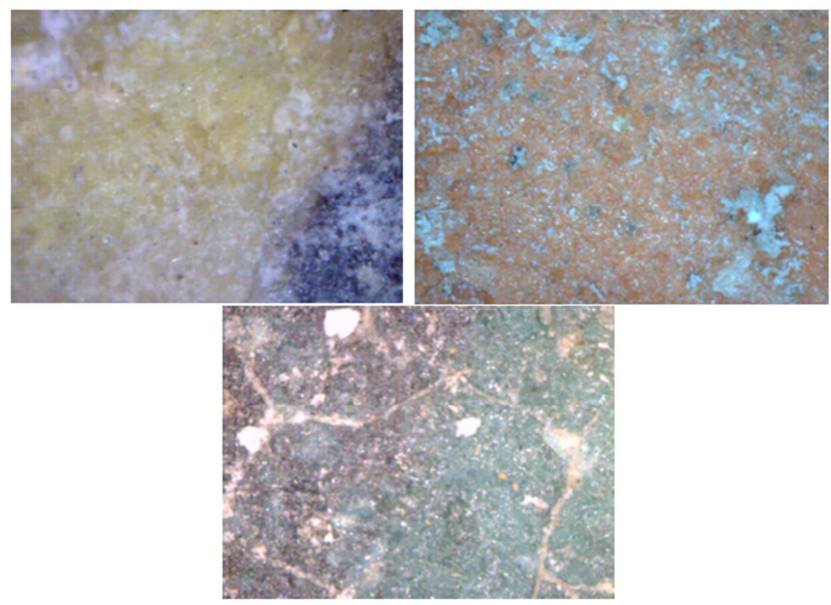

Fig. 3. Microscopic Picture of lolack, yellow, red, Green colors.

\subsection{Body and Glaze}

Besides the aforementioned, the object's exterior surface is almost of soft texture and regarding glaze thin layer is transparent and a little shiny. Body diameter is not the same in different areas. Brim diameter is low and toward object bottom the diameter gets more. The used glaze is colorless and with little diameter has covered the object's exterior and interior surfaces. Possibly the most important damage in object is related to the pot breaking and its transformation to large and small pieces having been connected to one another through paste. The breakages do not follow a certain pattern and piece 'size and form are different. Glaze scratch is observed as tiny lines. The scratches were produced because of inappropriate cleansing and / or in time of its usage and regarding application type at result of an object hit. This kind of scratch is more observed on the object's interior surface (Fig. 4).

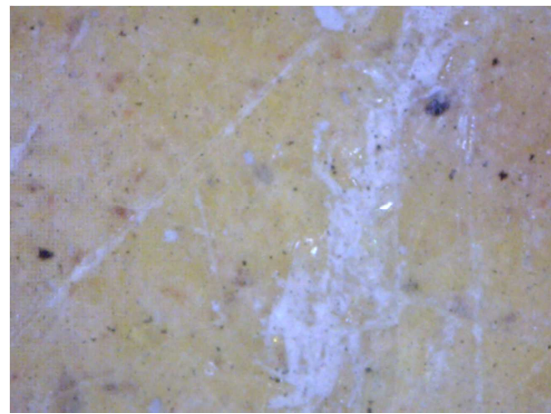

Fig 4. Scratch on object's surface. 
Glaze and color nick at result of hit to surface. These nicks are observed on the object's brim and bottom (Fig. 5) and if we presume its reason relating to crystallization of solved salts, laboratory studies will be needed.

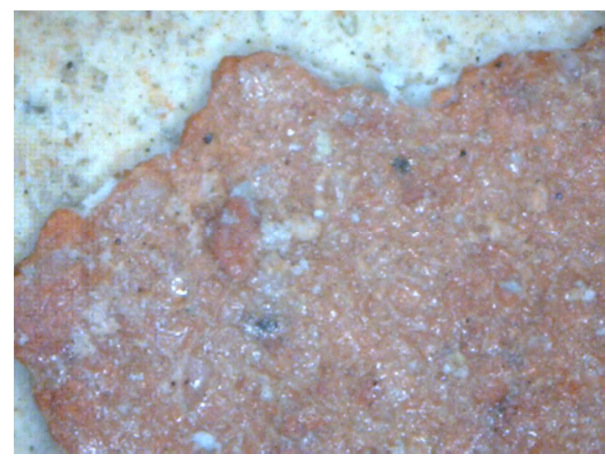

Fig. 5. Glaze and color nick.

Lack of some pieces: the object under study lacks in some parts, e.g., some areas of object's bottom and / or several parts of walls and brim. The rehabilitator, on this pot, has only tried to rehabilitate forms with materials not having similarity to the applied colors to the pot and it is easily recognizable. Motif and color of main section has not been executed in rehabilitation. Incongruous connector and use of inappropriate paste: distance between pieces are much and are of level difference. The used paste, probably wood paste, is inappropriate for connecting regarding color type. Color flaking and tearing off in some red parts are among other damages to the object. Description of object's main motifs: this kind of cream pots were being produced in the third and fourth (LY). These categories of potteries are actually made with less wittiness than to black and white potteries, but human sublime imagination and animal motifs decorations has led to their great attraction.

Pattern and motif of human statues in these pottery are of particular features, including rigid and firm form of marginal lines, rigid and angled forms, face rigidity, emphasis on marginal lines of face especially eyes and eyebrows, crosslegged way of sitting, cream background and special imitated procedures for ornamenting hair. In this clay pot, human statue is as full - length, with long skirt, standing while having a cup in one hand and another hand on waist has been drawn. Also, it seems that the statue holds two sharp wings. The portions of statue 's face like eyes' eyebrows, nose, lips are full -face, but the marginal line of face and chin has been drawn from three dimensional angle having given special and strange feature to the statue's face. The shirt's collar has been colored red and like the number seven. Characteristics like having wings have caused that the statue finds a superhuman and ultra-earth facet. The feet were drawn in sharp black shoes (boltlike). Bird motif has been drawn as an ornamental element on both sides of the bird's human statue (probably hoopoe), with emphasis on beak's long form, horn-like contortions of crest, and round and orbit projected eyes with checked wings. The bird's statue has been ornamented with black color and its wing with pattern of small arches mounted on one another as the symbol of its feathers. Its tail is summarized in that body shape and is not of independent exterior representation. Of unique points in this bird is its long and sharp beak that first goes upwards and then curves downwards. The other is shape and size of the bird's crest being much larger than bulk. The crest being from head's summit in the fairly same diameter as bird's neck and has been fully colored black is based on plant pattern that first ramifies and curves towards head front and the longest branch runs horizontally towards head back to near the status's end and contains several branches and cogs. Its size and shape are far from natural proportions with the bird's statue (Fig. 6 and 7).

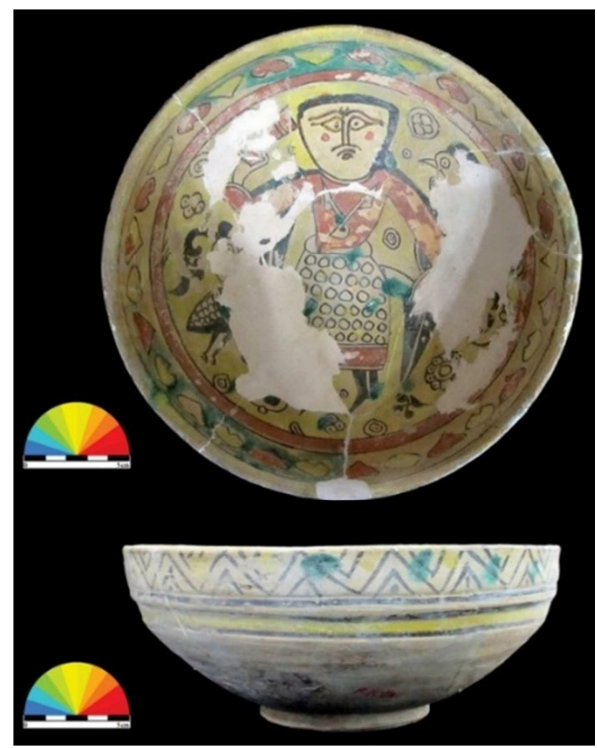

Fig. 6. Registered, 42380, Bowl's interior and Bowl's surrounding view, Bonyad Museum (Author).

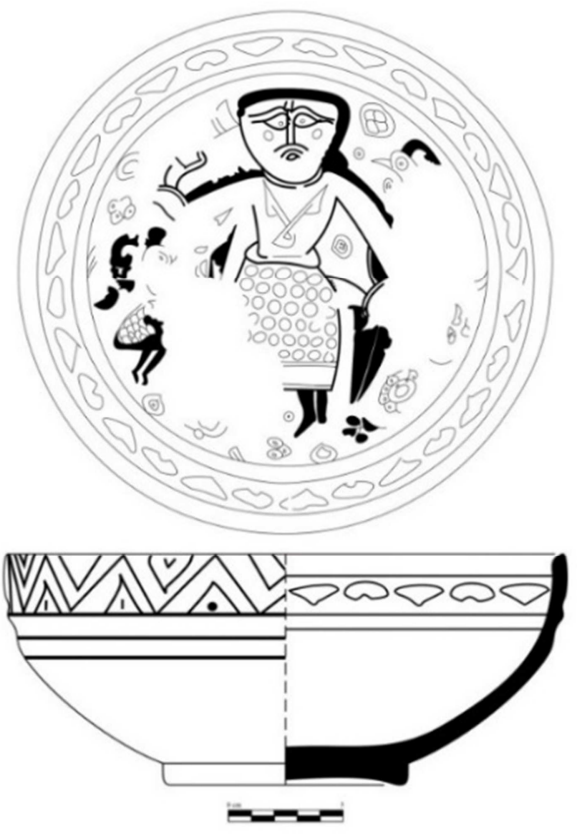

Fig. 7. Mouth diameter, 23cm, base diameter, 9/6 cm, Height, 9/5cm, (Author). 
In general the Picture of human statue and bird is of great similarity with the cases located in metropolitan museum: No. 38. 40.290 (Fig. 8).

Related to the third century (LY) and Nishapur, the other sample in Britain museum: No. 1959. 4 -13 (Fig. 9) and a sample in Tehran's raze Abbasi museum (Fig. 10) both related to the fourth century (LY) and Nishapur. Various and simple plant motifs are scattered all around the pot a heart motif has been drawn on the pot's margin in a relatively wide band with iteration.

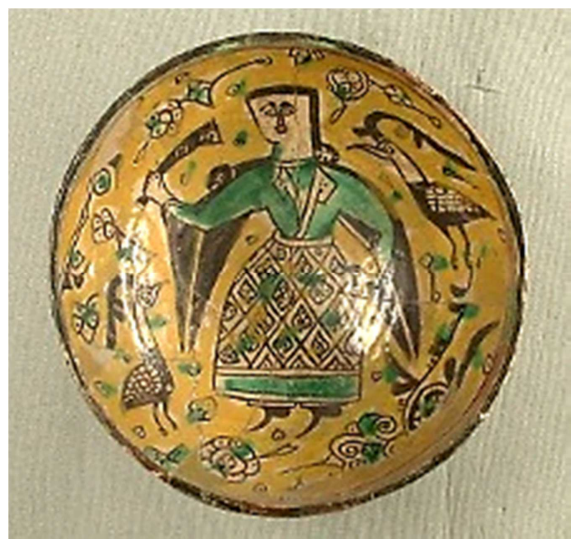

Fig. 8. Nishapur, $3^{\text {th }}$ century (LY), Metropolitan Museum: 38.40.290.

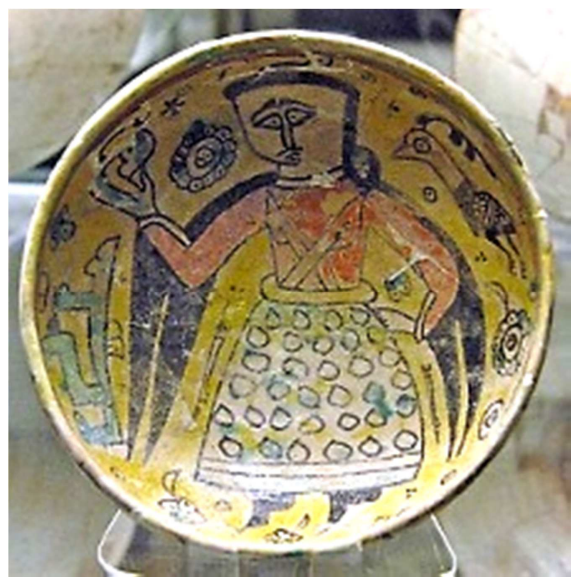

Fig. 9. Nishapur, $4^{\text {th }}$ century (LY), British Museum: 1959.4-13.

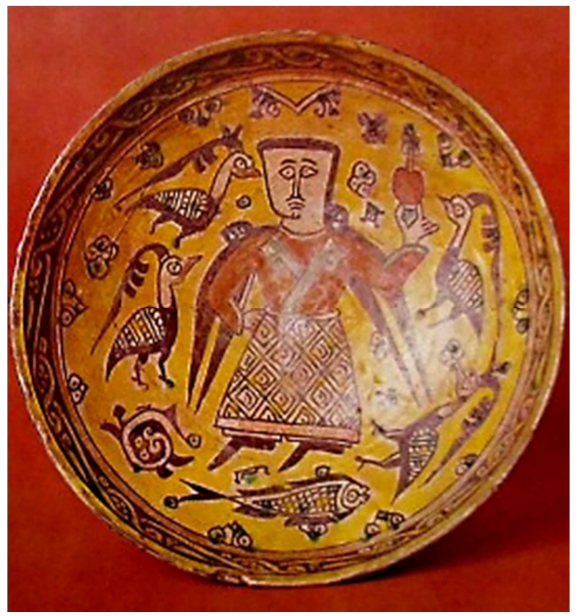

Fig. 10. Nishapur, $4^{\text {th }}$ century (LY), Reza Abasi Museum, No. 23. the pot's exterior ornamentation have been formed from brim with broken geometric lines and a plain band being congruent with a sample located in Reza Abbasi museum (Fig. 11) Related to the third century(LY) and Nishapur regarding ornament and form. This clay pot is of similarity with samples located in Metropolitan museum: No. 38. 40.290 (Fig. 12) related to the third century (LY) and Nishapur and the sample introduced in a book entitled with "in the pursuit of Parsee pottery": No. 40: Yoshida (Fig. 13) related to the fourth century (LY) and Nishapur regarding form. By considering similarity cases, this work is probably related to Nishapur and the third and fourth centuries (LY).

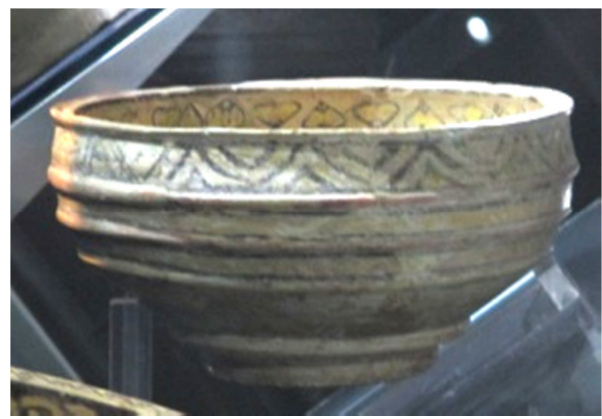

Fig. 11. Nishapur, $3^{\text {th }}$ century (LY), Reza Abasi Museum, No.231.

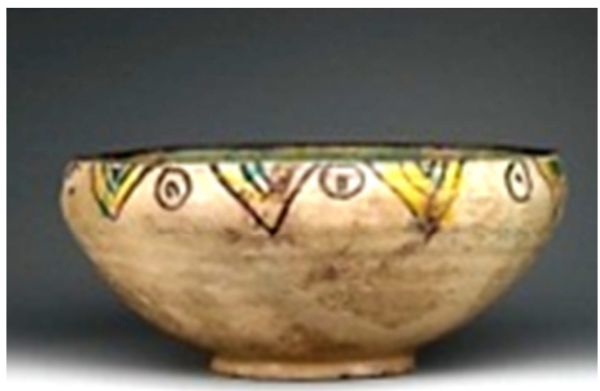

Fig. 12. Nishapur, $3^{\text {th }}$ century (LY), Metropolitan Museum: 38.40.290.

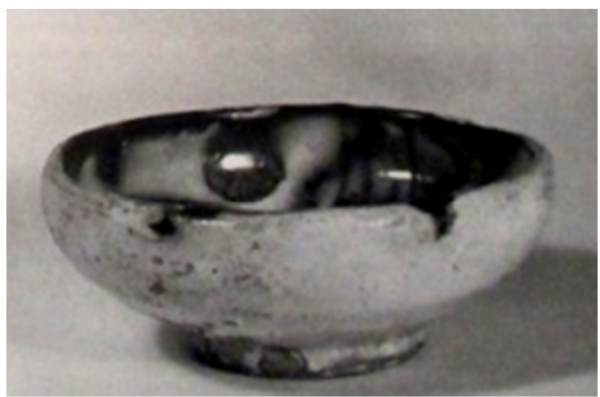

Fig. 13. Nishapur, $4^{\text {th }}$ century (LY), Yoshida, 1972:No. 40.

\section{Conclusion}

Use of slip painting technique started simultaneously with appearance of Iranian independent dynasties like Samanid and introduced as the most widespread and various kind of pottery in Islam's eastern lands. In spite of applying the same built technology in this kind of clay pot, variety in geometric, plant, animal, human and inscriptional patterns caused that these clay 
pots become known as a turning point in Islamic pottery art of early centuries. Human motifs are considered among the most complicated and mysterious ornamentation of Samanid art having been often created on slip painted Buff ware. Although in Islamic era, it was not typical to represent human and animal statues in non - religious arts, some samples with very beautiful imagery in case of slip painted Buff ware is observed. Tehran Bonyad Museum contains the most precious works in pottery treasury section. In this research sample of slip painted Buff ware motif of a human holding cup located in treasury of Tehran Bonyad Museum is studied and introduced that no information has already been published on it. Technical specifications and damage extent of this object were visually performed. This research embarks on relative dating and defining probable built place of the object under study through a descriptive - corresponding method that at the end by considering the most similarity items regarding motif and form and by corresponding study of the case under study with the rest of certificated similar samples in other collections and museums, the relative date of the third and fourth century (LY) was considered for this object and probably this case was of Nishapur's productions. The method for data gathering in this study was a filed - attributive one.

\section{References}

[1] Allen, J. W. 2004. cerámica islámica, una colección de arte islámico. Traductor M. Shayestehfar. Teherán: El Instituto de Arte Islámico.

[2] Bulliet, R. W. 1992, Pottery Style and Social Status in Medieval Khurasan, Archaeology, Annales and Ethnohistory, A. B. Knapp (ed.), Cambridge University press, PP. 75-82.

[3] Choubak, H. 2004. Jazmoryan cultural continuity of the old city of Jiroft in the Islamic period, Supervisor: Mohammad Yousef Kiani Islamic period archeology thesis. Tarbiat Modarres University.

[4] Demand, M. 1957. Industry Guide Islam. Translated by Abdullah Fryar. Tehran: Translation and Publication firm.

[5] Fehervari, G. 1973. Islamic pottery, a comperehensive study based on the Barlow Collection, London: Faber \& Faber.

[6] Fehervari, G. 2000, Ceramics of the Islamic world in the Taregh Rajab museum, London \& New York: I. B Tauris.

[7] Fitzherbert, T, 1983, Themes and Images on the Animated Buff Ware on Medieval Nishapur, a Unpublished M. phil Thesis, University of Oxford.

[8] Grube, E. j. 1976. Islamic Pottery of the Eight to the Fifteenth Century in the Keri Collection, London: Faber and Faber.

[9] Ghouchani, A. 1986. Inscriptions on Nishapur Pottery. Tehran: Ministury of Islamic Guidance

[10] Hosseini Yazdi Nejad, M. 2014. Evaluation of the non-writing pottery Nishapur (Ages 3 to $5 \mathrm{AH}$ ). MS Thesis, University of Kashan

[11] Keblow B \& Anne-Marie. 2003, Early Islamic Pottery Material and Techniques, Archetype Pablication, London
[12] Lane, A. 1948. Islamic Pottery from the Ninth to the Fourteen Centuries A. D in the Collection Sir. E. Hitchcock, Faber and Faber Limited, London.

[13] Morgan, P. 1994, Samanid Pottery, Type and Techniques, In: Cobalt And Luster, The First a Centuries of Islamic Pottery, Ernest Grube, The Nour Foundation In Association With b Azi Muth Editions and Oxford University Press Inc., Newyork, PP. 55-113.

[14] Mortezai, M. 2002. According to preliminary archaeological excavations in the area Jorjan first season of "archaeological reports 3, Tehran, Institute of Archaeology, 188-155.

[15] Mortezai, M \& Kiani, Mohammad Yousef. 2006. Study and analysis of pottery artifacts from archaeological excavations in the historical area Jorjan 2002 to 2005." Journal of Literature and Human Sciences, Tehran University, 2-180, 129-111.

[16] Mousavi Haji, S. R \& Atai, Morteza. 2010. The study of the pottery collection of Sistan. Zahedan: Administration of Cultural Heritage, Handicrafts and Tourism Organization of Sistan and Baluchestan.

[17] Mousavi, M. 1997 Archaeological excavations in the ancient city of Kish gruel." Archaeological reports 1, Institute of Archaeology, Tehran, 205-238.

[18] Pancaroglu, O. 2007. Perpetual Glory (Medieval Islamic Ceramics from The Harvey B. Plotntick Collection), Chicago, The art institute of Chicago.

[19] Rogers, M. 1995. Iranian pottery art. Under the supervision them. R. w. Fryh translation Parviz Marzban. Tehran: Forouzan, pp. 270-255.

[20] Shateri, M. Papel talla Cerámica en slip, 2009 especies, evolución y su lugar en la vida cultural, económica, basándose en las conclusiones de la cerámica en la época islámica de Alamut. Supervisor: Tulipanes Hayedeh, islámica tesis período de arqueología de la Universidad de Teherán.

[21] Shobeiri, D. 2010, The Study of Illustrations in Nishapur Samani pottery. MS Thesis, University of witness.

[22] Schrato, U. 1928. Samanid Art. Translated: Yaghoub Azhand. Tehran: Moulla.

[23] Tamaddon Yazdian, M. 2008. Typology of (review the techniques of construction and decoration) clay in the early Islamic period (first century until the end of the fourth AH) with an emphasis on works by Reza Abbasi Museum. MS Thesis, University of Alzahra.

[24] Vayh, G. 1984, arte en los primeros siglos del Islam. Traducción Rahman sarouji. Teherán.

[25] Wolf, H. 1994. antiguas artesanías iranies. Traductor Ciro Ebrahimzadeh. Teherán: Revolución y la formación islámica.

[26] Watson, O. 2004. Ceramics from Islamic Lands, the alsabah collection, Kuwait National Museum, United Kingdom: Thames \& Hudson.

[27] Wilkinson, Ch. 1973. Nishapur: Pottery of the Early Islamic Period, New York: The Metropolitan Museum Of Art.

[28] Yoshida, M. 1972. In Search Of Persian Pottery, Translated By John M. Shields, New York \& Tokyo \& Kyoto: Weatherhill / Tankosha. 
[29] Zamani A.1976. El efecto del arte Sasanian en el arte islámico. Teherán: Oficina del Ministerio de Cultura y el arte de la escritura.
[30] http://www.metmuseum.org/ (2014.06.28)

[31] http://www.britishmuseum.org/ (2014.07.05)

[32] Reza Abasi Museum (2014.07.05). 